\title{
THE BECOMING OF THE CREATIVE PERSONALITY: FROM CREATIVE POTENTIAL TO PROFESSIONALISM
}

УАК 159.928.955

\section{Сергій Шандрук \\ СТАНОВЛЕННЯ КРЕАТИВНӦ́ ОСОБИСТОСТІ: ВІД ТВОРЧОГО ПОТЕНЦІАЛУ ДО ПРОФЕСОНАЛІЗМУ}

Formulation of the scientific problem. Higher education system in Ukraine today is focused on new paradigmatics of innovatively productive researches, primarily aimed at the development of creative personality of the future specialist who is able not only to reproductive work but at the same time is able to implement effective problem-search work, to apply extraordinary, original variants of solutions professional tasks. Namely these circumstances are causing the essential target and form-structural reorientation of training system of future specialists, that's why the solution of these questions foresees the formation of a professional as a creative personality who is able to self-development, selfeducation, groundbreaking production labor.

Successfulness of achievement of given goal depends not only on what is learned (content of education), but on how thoroughly and most importantly - actively mastered: individually or collectively, in authoritarian or humanitarian conditions, relying on attention, perception, memory or pushed from personal-creative potential of human, with help of reproductive or active methods of learning and social impact. Indicated modalities of educational training indicate that while studying at university, the formation of future specialist requires processing of new approaches to the development and application of optimal system of methods and forms of teaching-productive activity of students to improve their professional competence, readiness to implement their own search mental activity, increase their creative potential and as a result the formation of a creative personality.
Singling out previously not singled parts of the general problem. Problems of development of abilities, creativity, creativity in the education process are considered by different scientists. Particularly general theoretical issues of development creative personality traits are highlighted in the works of B. G. Ananyev, D. B. Bohoyavlenska, L. I. Bozhovych, V. A. Krutetskiy, V. A. Romenets, V. O. Molyako, K. K. Platonov, Y. O. Ponomarev, V. V. Rybalka, A. V. Furman, M. O. Holodna, P. M. Yakobson and others; ways of development abilities of creative personality were the subject of research of V. I. Andreev, D. B. Bohoyavlenska, V. M. Druzhynin, O. M. Matiyshkin, V. V. Rybalka, S. O. Sysoyeva, P. I. Pidkasystyi and others. In addition, to the development of giftedness concept is dedicated scientific works of O. O. Bodalev, L. S. Vyhotskiy, O. G. Kovalev, V. A. Krutetskiy, V. O. Molyako, V. M. Myasyshchev, K. K. Platonov, S. L. Rubinstein, B. M. Teplov, V. D. Shadrikov and others. Notably, that creative potential of personality and conditions of abilities development as a component of creativity had studied such famous psychologists and philosophers like H. J. Eysenck, M. O. Berdyaev, L. S. Vyhotskiy, J. Guilford, V. M. Druzhynin, V. O. Molyako, Y. O. Ponomarev, V. V. Rybalka, V. A. Romenets, A. V. Furman, R. Steiner and others.

At the same time in psychologicallypedagogical literature on the development of creative abilities, giftedness, search creative activity of personality have found their realization mainly in the theory and practice of 
secondary schools. Regarding such issues as the definition of the psychological foundations of content, structure and organization of teachingproductive activity of university students, which contributes to both the formation and development of leading qualities of the creative personality and the full development of their professional creative abilities and creative potential, didn't receive enough theoretical substantiation and, moreover, applied illumination. Yet, we conducted a cycle of researches that make clear the nature and regularities of functioning and development of professional creative abilities of future psychologists (see. [12-14]).

Purpose of the article is a theoreticalmethodological substantiation of development creative potential as a precondition of becoming creative professional personality.

Presentation of the main material. The implementation in a higher school tasks in the bosom of forms and methods of educational process during training specialists to the future employment not only in the reproductive level of implementation, but also in creativeproductive, enables the achievement super task - to form a harmoniously developed, socially active and creative personality specialist who has a fundamental knowledge and capacity for creative self-development and self-education, can quickly solve extraordinary professional tasks and beforehand react to the social and business challenges and requests. On the personal development of specialist of system "humanhuman" the biggest impact have objective (objects, means and results of activity) and subjective (mental and social maturing, perfection of moral and spiritual consciousness, harmony of the system of values) factors [6, p. 277], which, in turn, causes the development of creatively mature personality. At the same time obviously that the achievement of delineated above goal foresees the change of psychoconceptual principles of organization everyday educational activity of students. And here important is reflexive delimitation and dialectical complementarity of forms, methods and means of indirect and prospective leadership by search cognitive activity of students (see. [10]). Besides, successfulness of this creatively oriented activity depends not only on the level of development formally personal but on heuristic-intuitive way of intellectual educational work, and thus on the completeness of subject-existential involvement of resources of creative abilities of future specialists.

In this analytical objective context of formation within walls of university a specialist with high creative competence as integral property of personality scilicet with systemic set of special knowledge, skills, motives, values, meanings and significant features-qualities that, for its part, ensures readiness for everyday realization of products of professional activity. With this, teaching-search productive work, carried out in the form of psycho-didactic innovation, is focused not so much on the study of already known, but on the combining it with unknown, on creation by participants their own educational products, as a result of what is optimizing the development of their the most necessary for the relevant branch or sphere of social practicing of skills and abilities, skills, competences. Simultaneously with it effectively is being received a different product of joint creative cooperation of teacher and student (scientific thesis or article, project, portfolio, work for the competition of student scientific works or for the student olympiad on specialty).

The becoming of a personality - is a showing of the human as a complete and responsible for themselves and surrounding subject of life activity which is capable of independent actions that outline peculiarities of functioning of valueregulatory sphere, which, in turn, reveals the depth of subjective causing of behavior, serves to the comprehension its consequences, produces authentic convictions, elaborates requirement, promotes reflexive evaluation and further enrichment of their own personal shifts of spiritualized self-creation [6, p. 275]. So, it is firstly is talking about the becoming of creative personality who is able to reveal own creative activity, situationally implement creative reserves and spiritual potential, combine individual qualities of carrier of creative potentials with the content of socially meaningful kind of activity, maximally involve creative mechanisms in the solving educational, professional and life problems .

The study and analysis of scientific literature gives reason to believe that the problem of creative potential was studied from different positions and was developed from different aspects:

firstly, creative potential of the personality was equal to some expressions of creative abilities, namely to the ability of personality to 
approach to a particular case unconventionally, to search and find the most appropriate ways, effective methods of solving newly arised problems [1], to the capacity to create, realize the resource of creative possibilities, finally to the ability of certain person perform creative actions; creative activity $[\mathbf{4}, 5]$;

secondly, creative potential of personality was considered as a set of linked into a single system of natural and acquired qualities which are detected through abilities, skills, actual mental processes, ways of thinking and activity and allow it unconventionally solve tasks, aimed at obtaining at the most effective way the maximal results [11];

thirdly, this potential was characterized as a such set of states and properties of personality, first of all as an integral personal property that is expressed in the attitude (position, installation, directivity) of the human to creativity [3]; and also as a systemic characteristics of personality, thanks to which it can create, make decisions, find something new, think unconventionally and act [15];

fourthly, under the creative potential were understood such characteristics as creative possibilities of the personality, its creativity that appears in thinking, communication and other kinds of activity, filling with content its psychodidactic world in general and separate abilities, products of creative activity and the process of their creation itself [2].

Based on the foregoing, vita-cultural methodology with its concept of professional methodologization and cyclically-deed approach in the development of science with its basic principles, concepts and regularities (A. V. Furman and his school [7-9]) self-organizational actualization of creative potential is considered by us as activity and ability of the personality which are linked with already formed skill to selfbalance itself as a highly complex substance of commitment that is detected in purposefulness, activity, argumentation of motivation, planning their own activity, independence, speed of making decisions and responsibility for them, criticality of evaluation the results of own actions, in calls of duty and self-respect. Such self-organization at the same time - it's an active mastering and transformation by individuality a creativity of external conditions of own life creativity in the actual creative relation-attitude to the world. So, there is every reason to single out such levels of self-organization of creative process of becoming of personality as synergistic conglomeration:
1. Teaching problem-dialogical situation as a channel of self-actualization in the context of productive activity - it's a process of realization by personality creative potential for solving creative tasks, problem solving, the result of which is its self-improvement, development of professional creative abilities and specialized competences. At that the main result of such personality in productive innovation-search activity is self-gaining by it a specific ability - professional creativity as a personal synergy that allows overcoming the unusual problems to solve creative tasks in real situations of everyday life and specialized activity.

2. Educational poli-motivation as an integral factor of self-prompting to creativity - it's a formed system of creative motives and abilities, desire to learn and transform the world, internal motivation for starting and developing a productive search-intellectual activity, which promotes a creative action of the personality because the core of creative existence is a thirst for the cognition and transformation of the world, which is internally and synergistically motivates to start an indicated activity, supports a desire to complete it, sometimes self-ensures return to this activity because of changing conditions. So, self-prompting to creative actions makes complex, dynamic, self-supportive system that enables the development of professional creative abilities in wide psycho-spiritual horizons of spontaneous existence of future or already formed professional.

3. Expanded deed action as a self-activity of creative process - it's a purpose and a means, but more precisely - self-purpose which is selfcaused, determines itself and prompts to creative action. In other words, the search self-activity is a subjective precondition of freedom, the will expressing, thinking, imagining, feelings and so on. Generally, for the creative personality is always situationally important to transfer such self-activity into the world of meanings, senses and samisnyh actions and then the situational energy of its organized existence transformed into social-cultural phenomenon - into the inner freedom of individuality who characterizes internally organized and embodied by real living creative potential of personality.

4. After-action self-reflection of the creative potential - it's a process, the essence of which is in comprehension by itself its own instincts and abilities to productive activity in the effective implementation of objective conditions and own creative capabilities to achieve the goals of the creative process. At that, during 
self-realization, the purpose is the ideal, thought forecasting of results of innovative-search work and also ways and mechanisms of its realization. It is clear that self-realization of creative potential foresees the usage of individual creative abilities of the subject of creativity and appearing in him a reflexive relation-attitude to himself as to personality and individuality. Namely this promotes becoming of personal worldview, the acquisition of new knowledge and techniques of creative work, and eventually allows the implementation of own experience through such activity and acts when professional creative abilities intensively are developing in specialist.

In our experience of theorizing the organization of productive learning activity of students is in its central link - creative committing:

- firstly, ensures their fully subjective involvement to cognitive educational creativity provided each of its participant objectivize by himself learning search activity and holistically realize all its stages: determines goals and tasks, analyzes material and means of implementation, performs procedures and complete set of actions, reflects its process and effectiveness;

- secondly, foresees the usage of holistic psychological-didactic system of keeping methods, means, conditions and parameters of such teaching-developmental space that causes active processing by the students new knowledge and ways of action in the process of individual and joint search, accelerates the becoming of their cognitive needs and interests, enables harmonious development of creative thinking, emotions, will;

- thirdly, achieves such compliance of norms and sense creation, at which intensifies the development psycho-spiritual culture of future professional as a highly qualified employee who personally internalizes, transforms, uses and enriches a sphere of values, received during mastering theoretical and applied training; at that carries out all this in favor of the most effective professional activity;

- fourthly, versatily promotes the formation of creative personality of professional by means of stimulation such traits-qualities as independence (personal standards of assessments and considerations), openness of mind (readiness to accept new and unusual solutions), high tolerance to uncertain and unsolved situations and constructive activity in these situations, developed aesthetic feelings, the ability to produce original ideas and nonstandard hypotheses concerning ways of solving simple and systemic problems.

\section{CONCLUSIONS}

1. Creative potential of personality of specialist-professional - it's an integral formation of the personality which enables actualization of creative motives and creative capabilities, realization of productive resources and potencies of a person as an individuality, internal self-movement of specialist to the professional self-realization and self-improvement, implementation of the intellectual-creative and thought-productive work, to the cyclically-action educational creation, involving at this cognitive, motivational, sensually-intuitive, creative and volitional resources to achieve the main goal of creative activity - creation of creative product.

2. Products of joint teaching-searching activity of participants in the educational space of university, aimed at developing the creative potential and becoming of the creative personality of professional are:

a) structured and actualized knowledge that act as a base of skills and abilities for successful solving of tasks of professional productive work;

b) the formulation by the students new goals and tasks that connected with the content of the searching learning activity and with regulation of their personal positions in educational time-space;

c) internal neoplasms of the psyche and thought activity in motivational, sensual, volitional, mental and value-semantic meaning contexts.

3. The above-mentioned psycho-developmental products become an integral part of individual experience and competence potential of a young human, where its structural organization, systemness, deepness, innovativeness determine eventually creative potential and productivity of professional in the future.

\section{THE LIST OF USED LITERATURE}

1. Кравчук П. Ф. Формирование развитой творческой личности студента (философско-социологический и методический аналіз) / П. Ф. Кравчук. - К.: Вища школа, 1984. - 154 с.

2. Курило Л. С. Розвиток творчого потенціалу дошкільника / Л. С. Курило // Культура і розвиток особистості: міфи та реалії в психології та педагогіці: матеріали Міжнародної науково-практичної конференції (24-25 червня 2009 р.) / За ред. І. Ю. Філіпової. Луцьк : Волин. нац. ун-т ім. Лесі Українки, 2009. - С. 190-194.

3. Матюшкин О. М. Концепция творческой одаренности / О. М. Матюшкин // Вопр. психол. - 1989. № 6. - C. 29-33. 
4. Моляко В. О. Здібності, творчість, обдарованість: теорія, методика, результати досліджень / В. О. Моляко, Л. О. Музика. - Житомир: Рута, 2006. - 320 с.

5. Психологічне дослідження творчого потенціалу особистості : [монографія] / наук. кер. авт. кол. В. О. Моляко; АПН України, Інститут психології ім. Г.С. Костюка. Лабораторія психології творчості. - К. : Педагогічна думка, 2008. - 207 с.

6. Фурман А. А. Психологія особистості: ціннісноорієнтаційний вимір : [монографія] / А. А. Фурман. Одеса : ОНПУ; Тернопіль: ТНЕУ, 2016. - 312 с.

7. Фурман A. В. Ідея і зміст професійного методологування : [монографія] / А. В. Фурман. - Тернопіль: THEУ, 2016. - $378 \mathrm{c}$.

8. Фурман A. В. Методологічне обгрунтування циклічно-вчинкової типології ігор / А. В. Фурман // Вітакультурний млин. - 2014. - Модуль 16. - С. 4-14.

9. Фурман А. В. Парадигми нормативності методологічного мислення у професійному становленні особистості / Анатолій В. Фурман // Соціально-психологічні виміри професійної майстерності особистості в умовах глобалізованого світу : матерали Міжнар. наук.- практ. конф. [Тернопіль, 16-17 трав. 2013 р.] // Психологія і суспільство. - 2013. - Спецвип. - С. 8-11.

10. Фурман А. В. Педагогічне керівництво пошуковою педагогічною активністю школярів : [монографія] / Анатолій В. Фурман, Богдан Скоморовський. - К.: Зодіак-ЕКО, 1996. - 112 с.

11. Хмельковська С. В. Формування творчого потенціалу майбутніх учителів іноземних мов у процесі фахової підготовки : автореф. дис... канд. пед. наук: 13.00 .04 / Хмельковська С. В. ; Південноукраїнський держ. педагогічний ун-т ім. К.Д.Ушинського (м. Одеса). - Одеса, 2005. - 20 с.

12. Шандрук $C$. Принципи побудови теоретичної моделі розвитку професійних творчих здібностей особистості практичного психолога / Сергій Шандрук // Психологія і суспільство. - 2015. - №4. - С. 107-121.

13. Шандрук $C$. К. Психологічні засади розвитку професійних творчих здібностей майбутніх практичних психологів : автореф. дис. на здоб. наук. ступеня доктора психологічних наук : 19.00.07 "Педагогічна та вікова психологія” / Сергій Костянтинович Шандрук. - Одеса, 2016. - $36 \mathrm{c}$.

14. Шандрук $C$. Творчість як употужнення здібностей особистості / Сергій Шандрук // Психологія і суспільство. - 2015. - №3. - С. 86-91.

15. Яковлева Е. Л. Психология развития творческого потенциала личности / Е. Л. Яковлева. - М., 1997. 224 c.

\section{REFERENCES}

1. Kravchuk P. F. Formyrovanye razvytoi tvorcheskoi lychnosty studenta (fylosofsko-sotsyolohycheskyi y metodycheskyi analiz)/P. F. Kravchuk. -Kyev : Vyshcha shkola, 1984. - 154 s. [In Russian].

2. Kurylo L. S. Rozvytok tvorchoho potentsialu doshkilnyka / L. S. Kurylo // Kultura i rozvytok osobystosti: mify ta realii $\mathrm{v}$ psykholohii ta pedahohitsi: materialy Mizhnarodnoi naukovo-praktychnoi konferentsii (24-25 chervnia 2009 r.) / Za red. I. Iu. Filipovoi. - Lutsk: Volyn. nats. un-t im. Lesi Ukrainky, 2009. - S. 190-194 [In Ukrainian].

3. Matiushkyn O. M. Kontseptsyia tvorcheskoi odarennosty / O. M. Matiushkyn // Vopr. psykhol. - 1989. - № 6. - S. 29-33 [In Russian].

4. Moliako V. O. Zdibnosti, tvorchist, obdarovanist: teoriia, metodyka, rezultaty doslidzhen / V. O. Moliako, L. O. Muzyka. - Zhytomyr: Ruta, 2006. - 320 s. [In Ukrainian].

5. Psykholohichne doslidzhennia tvorchoho potentsialu osobystosti : [monohrafiia]/ nauk. ker. avt. kol. V. O. Moliako; APN Ukrainy, Instytut psykholohii im. H.S. Kostiuka. Laboratoriia psykholohii tvorchosti. - K. : Pedahohichna dumka, 2008. - 207 s. [In Ukrainian].

6. Furman A. A. Psykholohiia osobystosti: tsinnisnooriientatsiinyi vymir : [monohrafiia] / A. A. Furman. Odesa : ONPU; Ternopil: TNEU, 2016. - 312 s. [In Ukrainian].

7. Furman A. V. Ideia i zmist profesiinoho metodolohuvannia : [monohrafiia] / A. V. Furman. -Ternopil: TNEU, 2016. - 378 s. [In Ukrainian].

8. Furman A. V. Metodolohichne obgruntuvannia tsyklichno-vchynkovoi typolohii ihor / A. V. Furman // Vitakulturnyi mlyn. - 2014. - Modul 16. - S. 4-14 [In Ukrainian].

9. Furman A. V. Paradyhmy normatyvnosti metodolohichnoho myslennia u profesiinomu stanovlenni osobystosti / Anatolii V. Furman // Sotsialno-psykholohichni vymiry profesiinoi maisternosti osobystosti v umovakh hlobalizovanoho svitu : materaly Mizhnar. nauk.- prakt. konf. [Ternopil, 16-17 trav. 2013 r.] // Psykholohiia i suspilstvo. - 2013. - Spetsvyp. - S. 8-11 [In Ukrainian].

10. Furman A.V. Pedahohichne kerivnytstvo poshukovoiu pedahohichnoiu aktyvnistiu shkoliariv : [monohrafiia] / Anatolii V. Furman, Bohdan Skomorovskyi. K.: Zodiak-EKO, 1996. - 112 s. [In Ukrainian].

11. Khmelkovska S. V. Formuvannia tvorchoho potentsialu maibutnikh uchyteliv inozemnykh mov $\mathrm{u}$ protsesi fakhovoi pidhotovky : avtoref. dys... kand. ped. nauk: 13.00.04 / Khmelkovska S. V. ; Pivdennoukrainskyi derzh. pedahohichnyi un- $\mathrm{t}$ im. K.D.Ushynskoho (m. Odesa). - Odesa, 2005. - 20 s. [In Ukrainian].

12. Shandruk S. Pryntsypy pobudovy teoretychnoi modeli rozvytku profesiinykh tvorchykh zdibnostei osobystosti praktychnoho psykholoha / Serhii Shandruk / / Psykholohiia i suspilstvo. - 2015. - №4. - S. 107-121 [In Ukrainian].

13. Shandruk S.K. Psykholohichni zasady rozvytku profesiinykh tvorchykh zdibnostei maibutnikh praktychnykh psykholohiv : avtoref. dys. na zdob. nauk. stupenia doktora psykholohichnykh nauk : 19.00.07 "Pedahohichna ta vikova psykholohiia" / Serhii Kostiantynovych Shandruk. - Odesa, 2016. - 36 s. [In Ukrainian].

14. Shandruk S. Tvorchist yak upotuzhnennia zdibnostei osobystosti / Serhii Shandruk // Psykholohiia i suspilstvo. - 2015. - №3. - S. 86-91 [In Ukrainian].

15. Yakovleva E. L. Psykholohyia razvytyia tvorcheskoho potentsyala lychnosty / E. L. Yakovleva. - M., 1997. - 224 s. [In Russian]. 


\section{АНОТАЦІя}

\section{Шандрук Сергій Костянтинович.}

Становлення креативної особистості: від творчого потенціалу до професіоналізму.

Дослідження актуалізує проблематику формування креативної особистості й різнобічно обгрунтовує розвиток творчого потенціалу професіонала як мету і завдання підготовки висококваліфікованих фахівців, здатних до продуктивного розв'язання проблемних ситуацій і виробничих завдань. Актуалізація творчого потенціалу розглядається як діяльність і як спроможність особистості фахівця-професіонала, котрі пов'язані зі сформованим умінням самозбалансувати себе як надскладну субстанцію вчинення, що виявляється у цілеспрямованості, активності, аргументованості мотивації, плануванні власної роботи, самостійності, швидкості прийняття рішень і відповідальності за них, критичності оцінки результатів власних дій, у почуттях обов'язку і самоповаги. Доведено, що максимальний ефект креативної діяльності досяжний за умови, коли всі елементи і підсистеми працюють в одному напрямку - задля створення якісного продукту творчості, що супроводжується посиленням креативного потенціалу особистості, який унаявнений широким спектром інтелектуальних, мотиваційних, комунікативних та професійних властивостей, котрі уможливлюють творче зреалізування професійності, у тому числі й продуктивне розв'язання проблем і трудових завдань, гарантують оригінальність, ефективність та позитивний результат творчої праці.

Ключові слова: навчальний процес, креативність, творчий потенціал, креативна особистість, здібності, проблемна ситуація, професійна діяльність, творчі мотиви, креативні спроможності, інтелект, оригінальність, творчий продукт, особистість.

\section{АННОТАЦИЯ}

\section{Шандрук Сергей Константинович.}

Становление креативной личности: от творческого потенциала к профессионализму.

Исследование актуализирует проблематику формирования креативной личности и разносторонне обосновывает развитие творческого потенциала специалиста как цели подготовки высококвалифицированных специалистов, способных к продуктивному решению проблемных ситуаций и производственных задач. Актуализация творческого потенциала рассматривается как деятельность и как способность личности специалиста-профессионала, которые связаны со сложившимся умением самосбалансирования себя как сложнейшей субстанции совершенствования и которые состоят в целеустремленности, активности, аргументированности мотивации, планировании своей работы, самостоятельности, скорости принятия решений и ответственности за них, критичности оценки результатов собственных действий, в чувствах долга и самоуважения. Доказано, что максимальный эффект креативной деятельности достижим при условии, что все элементы и подсистемы будут работать в одном направлении - для создания качественного продукта творчества, что сопровождается усилением креативного потенциала личности, который объективированный широким спектром интеллектуальных, мотивационных, коммуникативных, профессиональных свойств и предполагает творческую реализацию профессионализма, в том числе и продуктивное решение проблем и трудовых задач, гарантируют оригинальность, эффективность и положительный результат творческого труда.

Ключевые слова: учебный процесс, креативность, творческий потенциал, креативная личность, способности, проблемная ситуация, профессиональная деятельность, творческие мотивы, креативные способности, интеллект, оригинальность, творческий продукт, личность.

\section{ANNOTATION}

\section{Shandruk Serhiy.}

The becoming of the creative personality: from creative potential to professionalism.

The research actualizes the problematic of formation the creative personality and versatily substantiates the development of creative potential of professional as a goal and task of training highly qualified specialists capable to productive solving of problematic situations and productive tasks. Actualization of creative potential is considered both as an activity and as an ability of the personality of specialist-professional which are linked with already formed skill to self-balance itself as a highly complex substance of commitment that is detected in purposefulness, activity, argumentation of motivation, planning their own work, independence, speed of making decisions and responsibility for them, criticality of evaluation the results of own actions, in calls of duty and self-respect. It was proved that maximal effect of creative activity is achievable provided all elements and subsystems operate in one direction - for creation a quality product of creativity that accompanied by enhancement of the creative potential of the personality which is appeared by wide range of intellectual, motivational, communicative and professional properties which enable creative realization of professionalism, including productive problem and labor tasks solving, guarantee originality, efficiency and positive result of creative work.

Keywords: learning process, creativity, creative potential, creative personality, abilities, problem situation, professional activity, creative motives, creative capabilities, intellect, originality, creative product, personality.

Надійшла до редакції 6.02.2017. 